\title{
Microbiological Analysis and Concentration of Organic Dust in an Herb Processing Plant
}

\author{
Kazimierz Zawišlak ${ }^{1}$, Paweł Sobczak ${ }^{1 *}$, Marta Kozak ${ }^{1}$, Jacek Mazur ${ }^{1}$, \\ Marian Panasiewicz ${ }^{1}$, Wioletta Żukiewicz-Sobczak ${ }^{2}$, \\ Janusz Wojdalski ${ }^{3}$, Leszek Mieszkalski ${ }^{3}$ \\ ${ }^{1}$ Department of Food Engineering and Machines, University of Life Sciences in Lublin, Lublin, Poland \\ ${ }^{2}$ Department of Public Health, Pope John Paul II State School of Higher Education in Biała Podlaska, \\ Biała Podlaska, Poland \\ ${ }^{3}$ Department of Production Organization and Engineering, Warsaw University of Life Sciences
}

Received: 14 May 2018

Accepted: 23 July 2018

\begin{abstract}
In the dust of organic plant origin the presence of micro organisms, particularly moulds and endotoxins, is recorded to have harmful effects on the human body and cause many diseases. The microbiological quality of the processed plants is largely dependent on the fragment of the plant used as raw material, since the microbial contaminants are the result of different contacts of each particular part of the plant with the external environment during cultivation and further processing. Organic dust present in the plant raw material may be varied not only in terms of microbial contamination, but also regarding the size of particles thereof. In the presented study an attempt was made to identify fungi found in the organic dust sampled in an herb processing plant located in eastern Poland. The concentrations of PM10 and PM 1.0 were determined within two production lines, and these values were then referred to the existing regulations. The mean concentration of PM10 significantly exceeded the alert level.
\end{abstract}

Keywords: dust; contamination; moulds, herb industry; environment

\section{Introduction}

The food industry is still facing the problem of dust present during the processing and storage of products such as herbs and cereals. Therefore, special attention is paid to the protection of workers against negative effects of the presence of dust at various stages of production $[1,2]$. Hence, at the beginning measurements of dust

*e-mail: pawel.sobczak@up.lublin.pl concentration at the affected workstations are made and then the rates of exposure to it in relation to a full-time working day are determined. These are compared with the values of the maximum allowable concentration of dust (MAC). If the rate values are higher than MAC, then the employer should immediately undertake action to minimize the concentration of harmful substances in the work environment to the acceptable level. Assessment of dust contamination in herbal industry is a complex process that aims not only to determine the amount of detected substances in the work environment, but also to identify their composition and the importance for the 
health of workers. Sampling of air can be performed either by using stationary instruments (sampling in a specified fixed point within the work environment), or by individual devices installed on an employee and equipped with a measuring probe located in the breathing zone (as close as possible to the respiratory tract of an employee) [3-5].

Dust may occur at various stages of production. Pulverization, screening, conveying and mixing are classified as being among the most dust-creating processes. Organic dusts of plant origin are particularly dangerous in biological terms. Typically such dusts are mixtures of plant particles and inorganic microorganisms as well as substances produced by them. Most plant dust contains micro-organisms such as gram-negative bacteria, thermophilic actinomycetes, moulds, and endotoxins. This kind of dust also contains free silica $\left(\mathrm{SiO}_{2}\right)$, whose levels during the initial phase of the processing of plant raw material can reach up to $60 \%$ depending on the type of soil, and in the further stages of processing they drop below $10 \%[1,2$, $6]$.

Organic dusts of plant origin are varied in terms of particle size composition. The largest size fraction present in plant dusts is composed of particles of the size $<5 \mu \mathrm{m}$, and it can account for between 40 and $98 \%$ of the dust sample. The composition, fraction size, and type of workstation all affect the amount of dust inhaled by workers; it can range from fractions of milligrams to even 100 milligrams in $1 \mathrm{~m}^{3}$ of air [7, 8]. Organic dust present in air, whose particles have a diameter greater than $10 \mu \mathrm{m}$ falls quickly on surfaces and is called settling dust. On the other hand, smaller particle fractions remain suspended in the air. Particle fraction $\mathrm{PM}_{10}$ consists of particles smaller than $10 \mu \mathrm{m}$, while the particle fraction $\mathrm{PM}_{1.0}$ are those with a diameter smaller than $1 \mu \mathrm{m}$. The impact of such air pollution depends on the chemical composition, the type of substances absorbed on the surface, etc. Dust particles with a diameter smaller than $10 \mu \mathrm{m}$ enter the respiratory tract with breathing air. The smaller particles are more harmful because if their size is smaller than $1.0 \mu \mathrm{m}$ they can enter alveoli [9].

Dusts present in food processing plants may cause a number of diseases, including asthma, pneumoconiosis, and lung cancer as the mould spores as well as endotoxins can very easily penetrate the human body. Employees exposed to them most often report respiratory ailments, inter alia: dry cough, shortness of breath, decreased lung function and asthma exacerbation, as well as digestive system problems [8, 10-12]. In addition, these individuals may exhibit symptoms of developing inflammation such as: increased body temperature, chills, decreased blood pressure, hypoglycaemia, as well as pathological changes in the blood, e.g., an increased number of leukocytes. Moreover, endotoxins cause conjunctival irritation as well as congestion of nasal mucosa. Typically, the symptoms of diseases caused by agricultural dust appear only after a few hours once finishing the work [2].

Health effects in people exposed to inhalation of dust present in the air depends not only on the size and shape of the particles, but also on the chemical and microbiological composition of the dust and its concentration. The studies carried out in recent years have shown a high degree of exposure to airborne micro-organisms, in the range of 105-106 thousand $\mathrm{cfu} / \mathrm{m}$, when processing herbs, similarly as in the case of performing most of agricultural work [13-15].

Medicinal herbs and spices can be affected by primary contamination with microorganisms inhabiting soil, water and air as well as by secondary ones if adequate sanitary conditions during processing, transport or storage are not maintained. The main sources of plant contamination are bacteria, actinomycetes and moulds, especially of the genus Aspergillus, Penicillium, Alternaria, and Fusarium. Pathogenic bacteria that in natural conditions do not occur among plants, but for which human beings might be a reservoir, are the other important pathogens of herbal raw material. These include: Salmonella typhimurium, Listeria monocytogenes, Enterococcus faecalis, Yersinia enterocolitica, and Escherichia coli - all of which cause food poisoning $[1,6$, 15-17].

The amount of mould in herbal raw material is also dependent on the moisture content and plant environment, including temperature and oxygen availability. Regardless of the source of microbial contamination, affected plant raw material may contribute to the induction of adverse health effects in consumers. Children, the elderly, and people with compromised immune systems are particularly exposed to the pathogenic microorganisms. This is especially important because herbs usually do not undergo culinary treatment [13, 17-19].

The greatest danger is posed by mycotoxins, which are metabolites of moulds mainly of the genera Aspergillus, Penicillium, etc. They can cause pathogenic effects of a chronic, subacute or acute nature. Additionally, they exhibit carcinogenic, mutagenic, teratogenic, and neurotoxic effects. They might cause liver damage, decrease resistance to infection, contribute to fertility disorders, and even accelerate the development of kidney, liver, colon, duodenum, stomach and esophagus tumors. Although acute poisoning with mycotoxins occurs quite rarely, there are often cases of long-term effects of small doses of these toxins on the body $[6,20]$.

Moulds of the genera Penicillium and Aspergillus pose the greatest threat to the employees of herb processing plants. They may cause, inter alia, respiratory diseases of allergic origin, such as extrinsic allergic alveolitis - EAA - alveolitis alergica, bronchial asthma, allergic rhinitis, allergic conjunctivitis, and diseases caused by immunotoxicants - aspergillosis, organic dust toxic syndrome - ODTS [21, 22]. 
Table 1. Concentrations of dust at particular points in the plant.

\begin{tabular}{|c|c|c|c|c|c|}
\hline Location & $\begin{array}{c}\text { Fraction size } \\
{[\mu \mathrm{m}]}\end{array}$ & $\begin{array}{c}\text { Temporary dust } \\
\text { concentration max. value } \\
\left(\mathrm{mg} / \mathrm{m}^{3}\right)\end{array}$ & $\begin{array}{c}\text { Temporary dust } \\
\text { concentration min. value } \\
\left(\mathrm{mg} / \mathrm{m}^{3}\right)\end{array}$ & $\begin{array}{c}\text { Dust concentration } \\
\text { avg. value }\left(\mathrm{mg} / \mathrm{m}^{3}\right)\end{array}$ & $\begin{array}{c}\text { SD dust } \\
\text { concentration }\end{array}$ \\
\hline \multirow{3}{*}{ Line - 1} & $\mathrm{PM}_{1}$ & 0.133 & 0.116 & 0.1257 & 0.0044 \\
\cline { 2 - 6 } Line - 2 & $\mathrm{PM}_{10}$ & 0.789 & 0.504 & 0.6186 & 0.0675 \\
\cline { 2 - 6 } & $\mathrm{PM}_{1}$ & 0.284 & 0.130 & 0.1690 & 0.0358 \\
\hline \multirow{2}{*}{ Packaging } & $\mathrm{PM}_{10}$ & 2.160 & 0.851 & 0.1056 & 0.3175 \\
\cline { 2 - 6 } & $\mathrm{PM}_{1}$ & 0.143 & 0.073 & 0.1740 & 0.0200 \\
\hline \multirow{2}{*}{ Outside } & $\mathrm{PM}_{10}$ & 0.248 & 0.132 & 0.0381 & 0.0102 \\
\cline { 2 - 6 } & $\mathrm{PM}_{1}$ & 0.073 & 0.029 & 0.1256 & 0.0812 \\
\hline
\end{tabular}

The aim of our study was to determinate levels of dust concentration in an herb processing plant as well as identifying the fungus found in the collected samples of organic dust, and evaluating their quantity.

\section{Experimental Procedures}

\section{Selecting Air Sampling Points}

In the first stage the four measuring points of air sampling were selected. The first two points were set within the technological lines for cleaning, separation, and the initial packaging of herbs located in two separated production halls, where various herbal raw materials are treated. The first technological line is for thyme (Thymus vulgaris) treatment, while the second is for cistus (Cistus incanus) treatment. The third point was located in a closed room of the facility designed for packaging herbs in individual packages. The fourth measurement point was located outside, directly in front of the herbal plant, in a spot where the transportation of raw materials takes place (Fig. 1).

\section{Measuring Dust Concentration in the Air}

Then, at each of the selected points identical analyses were carried out. The measurement of the dust concentration in the air was made using a DustTrak II aerosol monitor. The operation of the device is based on the use of a laser light photometer, which enables measurement of the concentration of aerosols in the tested air in real time. The size-selective impactor is composed of three parts: the cap, impaction plate and bottom. Selection of the cap determines cut size of the impactor. For analysis of the dust concentration in the examined plant, two caps of sizes 1 and $10 \mu \mathrm{m}$ respectively were used. The same impaction plate

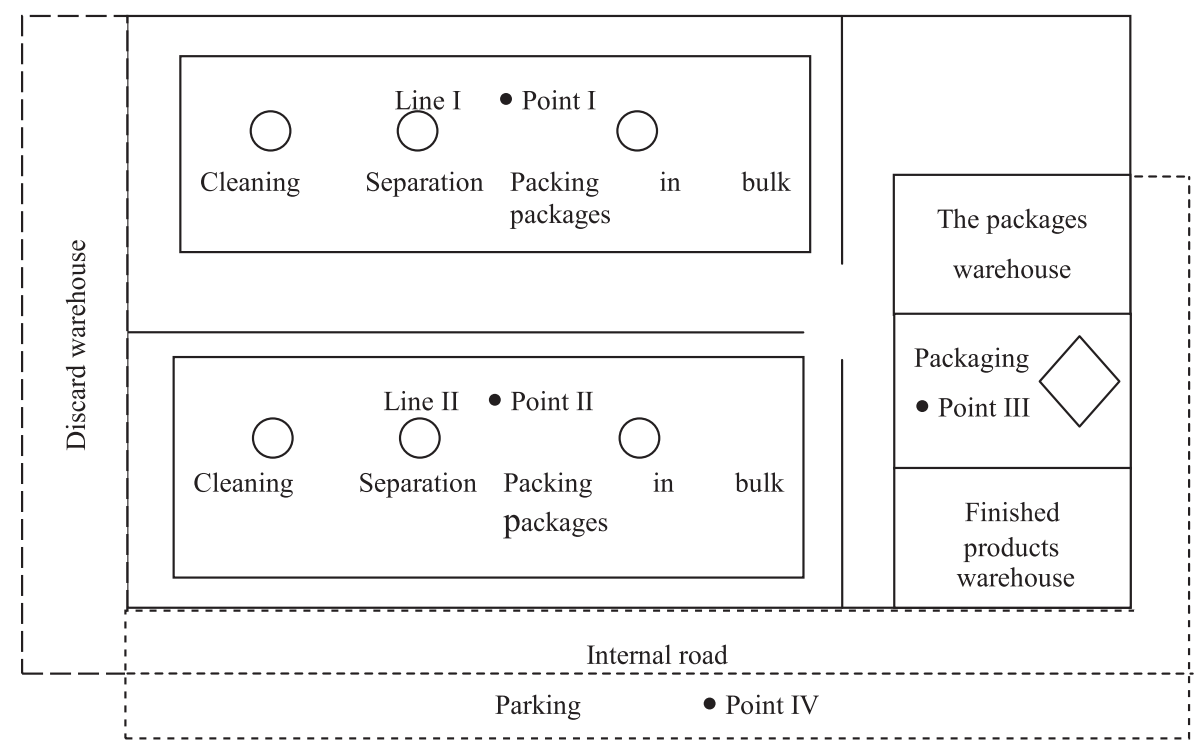

Fig. 1. Schematic layout of the herb processing plant. 
and bottom were used on all impactor sizes. During monitoring, the 1-minute average concentrations of $\mathrm{PM}_{10}$ and $\mathrm{PM}_{1}$ were recorded on a data storage card. The analysis was performed during the working hours of the plant, i.e., between 08:00 and 15:00, at 1-hour intervals ( 8 repetitions) for 5 consecutive working days. On the basis of the collected results, the minimum and maximum dust concentrations were determined and the average value and standard deviation were calculated.

\section{Determining the Number and Identification of the Species of Fungi}

The next stage of the study consisted of determining the number and identification of the species of fungi present in the particular fractions of the dust collected from the production lines. Samples of accumulated dust were collected directly from devices being a part of the production lines located within the production hall. The analyses were performed using two culture media: MA (Malt Agar) and PDA (Potato Dextrose Agar). Samples of $1 \mathrm{~g}$ were transferred to a $50 \mathrm{ml}$ sterile falcon test tubes, and then dilluted with distilled water to prepare dilutions from $10^{-1}$ up to $10^{-4}$. The next stage involved the application of the prepared dilution on a Petri dish with a standardized culture medium (PDA and MA). The plates prepared in that manner were then incubated for 72 hours at a temperature dependent on the type of substrate used: $24^{\circ} \mathrm{C}$ for PDA, and $30^{\circ} \mathrm{C}$ for MA [23-25]. After the time elapsed, all grown colonies were counted, and the number of colony-forming units (CFU/g) present in the tested samples were calculated using the following formula:

$$
L=\frac{C}{N_{1}+0.1 N_{2}} \cdot d
$$

...where:

$\mathrm{C}$ - sum of all colonies on all plates counted

$\mathrm{N}_{1}$ - number of plates in first dilution counted

$\mathrm{N}_{2}$ - number of plates in second dilution counted

$\mathrm{d}$ - dilution factor corresponding to the first (lowest) dilution from which the first counts were obtained [26]

For the counting plates from 2 successive dilutions are selected, on which between 30 and 300 colonies had been grown.

The analyses of the qualitative composition were performed on the basis of the macro- and microscopic characteristics and with the use of selected items of taxonomic literature $[25,26]$.

\section{Results and Discussion}

\section{Concentration of Organic Dust in the Air}

The results of the measurements of the concentration of organic dust in the air at selected points of the plant are shown in Table 1. The evaluation of sanitary working conditions was conducted on the basis of the MAC value for dusts of plant and animal origin. For the dusts with the free crystalline silica content above $10 \%$ the maximum allowable concentration of total dust equals $0.05 \mathrm{mg} / \mathrm{m}^{3}$ per 24 hours, while for respirable dust it is $0.025 \mathrm{mg} / \mathrm{m}^{3}$. Sources of silica in dust include sand from soil used for cultivation and silicic acid contained in organic substances [27]. According to the Regulation of the Minister for the Environment from 2012, the reporting level for particulate matter $\mathrm{PM}_{10}$ is $0.200 \mathrm{mg}$ / $\mathrm{m}^{3}$, and the alarm level equals $0.300 \mathrm{mg} / \mathrm{m}^{3}$ [28].

The analysis of the dust concentration showed that at the measuring point located at line II, the highest recorded concentration of dust for short-term exposure was $\mathrm{PM}_{10}=2.16 \mathrm{mg} / \mathrm{m}^{3}$, which is high above the acceptable limit (7.2 times of the alarm level). The average concentration of particulate matter within the studied lines was too high and it significantly exceeded the maximum alarm level.

The concentration of dust present in the air within the processing lines for herb treatment varied depending on the type of raw material cleaned. The lowest concentration of aerosols was reported at the stage of final packaging $\left(\mathrm{PM}_{10}=0.1754 \mathrm{mg} / \mathrm{m}^{3}\right.$, $\mathrm{PM}_{1}=0,1056 \mathrm{mg} / \mathrm{m}^{3}$ ), thanks to using an automatic packing machine for this purpose, which limits the release of dust particles to the outside.

The results obtained are similar to those from the analyses carried out by Sobczak et al. [29], examining the dust concentration on selected workstations in feed plants in Lublin Province, where similarly the mean values of dust concentration did not exceed $2 \mathrm{mg} / \mathrm{m}^{3}$. As in the case of the plant presently examined the mean concentration of dust at the packaging stage was at the level of $0.11 \mathrm{mg} / \mathrm{m}^{3}$, and the highest concentration of inhaled dust $(<1 \mu \mathrm{m})$ was present at the pulverization stage and equalled $0.2510 \mathrm{mg} / \mathrm{m}^{3}$. At the same time, it was about twice as high as within the production lines of the analyzed plant, which results from the automation of its machinery.

Plants for processing biomass for energy purposes have similar dust concentration as establishments for herb processing, which is confirmed by the results of the research conducted by Szulc et al. [5], who determined the level of dust concentration in a power plant in Poland. The authors showed that in tunnels for transportation and storage of wood biomass the concentration of the aerosols of the fraction size of $1 \mu \mathrm{m}$ was at the level of $\mathrm{PM}_{1}=0.158 \mathrm{mg} / \mathrm{m}^{3}$, while in the case of dust particle of the size of $10 \mu \mathrm{m}$ it was $\mathrm{PM}_{10}=0.260 \mathrm{~g} / \mathrm{m}^{3}$. During the unloading of biomass supplies by the employees the concentration of dust fractions increased three-fold as the result of mixing and floating of organic particles. In the case of the fraction size of $1 \mu \mathrm{m}$ it reached $\mathrm{PM}_{1}=0.395 \mathrm{mg} / \mathrm{m}^{3}$, while in the case of particle size of $10 \mu \mathrm{m}$ to $\mathrm{PM}_{10}=0.815 \mathrm{~g} / \mathrm{m}^{3}$, respectively.

The results of the research attest that the average aerosol concentration at the workstation of a packer in cereal and milling plants is very similar to the 
Table 2. Numbers of grown mould colonies (cfu/g).

\begin{tabular}{|c|c|c|c|c|c|}
\hline Point & Type of Species & Dilution & Type of Medium & Result & Total Content \\
\hline \multirow{8}{*}{$\begin{array}{c}\mathrm{I} \\
\text { (Line I) }\end{array}$} & & -1 & \multirow{4}{*}{ MA } & Uncountable & \multirow{4}{*}{1182} \\
\hline & Peniscilium sp. Citriunum & -2 & & 31 & \\
\hline & Penicilium sp. & -3 & & 9 & \\
\hline & & -4 & & 0 & \\
\hline & & -1 & \multirow{4}{*}{ PDA } & Uncountable & \multirow{4}{*}{7000} \\
\hline & $\begin{array}{l}\text { Aspergillus sp. Fumigatus } \\
\text { Peniscilium sp. Citriunum }\end{array}$ & -2 & & 123 & \\
\hline & Peniscilium sp..Citriunum & -3 & & 31 & \\
\hline & & -4 & & 0 & \\
\hline \multirow{8}{*}{$\begin{array}{c}\text { II } \\
\text { (Line II) }\end{array}$} & & -1 & \multirow{4}{*}{ MA } & Uncountable & \multirow{4}{*}{3454} \\
\hline & Aspergillus sp. & -2 & & 60 & \\
\hline & Aspergillus sp. & -3 & & 16 & \\
\hline & & -4 & & 0 & \\
\hline & & -1 & \multirow{4}{*}{ PDA } & Uncountable & \multirow{4}{*}{12544} \\
\hline & $\begin{array}{l}\text { Aspergillus sp. } \\
\text { Alternaria sp. Alternata }\end{array}$ & -2 & & 230 & \\
\hline & Penicilium sp. & -3 & & 46 & \\
\hline & & -4 & & 0 & \\
\hline
\end{tabular}

results obtained in the course of examination of the herb processing facility, and it is at the level of $0.10 \mathrm{mg} / \mathrm{m}^{3}$. However, the dust concentration at the other workstations in the grain processing plants exceeds the maximum allowable concentration even several times. For example, at the workstation of an elevator operator it amounts to about $23 \mathrm{mg} / \mathrm{m}^{3}$ [30]. The research conducted by Karpaciński [4] also confirms a much higher level of dust concentration in industrial mills, where the aerosol concentration detected was higher than $10 \mathrm{mg} / \mathrm{m}^{3}$.

\section{Number and Species of Fungi}

All grown colonies of mould on various substrates are summarized in Table 2. The dust samples collected from line II, where cistus is processed, displayed much higher levels of mould. In total, $2,418 \cdot 10^{4}$ mould colonies were counted for both production lines that grew on PDA and MA substrates. On the basis of macro- and microscopic characteristics, among the mould colonies grown from the dust coming from the first line the following species were isolated: Aspergillus fumigatus and Penicillium Citriunum. For the second production line the dust consisted of such species as Alternaria Alternata, Aspergillus Fumigatus, and Penicilium Citriunum. The differences in both the number and type of microbes in the plant dust may be associated with different morphological structure of the plants and other cultivation conditions.
In the case of the examined samples, more mould colonies were recorded on PDA, which is consistent with the results of the research on the impact of the incubation medium on the number and species composition of isolated fungi [31].

At present, there are neither standards nor regulations regarding the classification of premises due to the number of micro-organisms present in the air thereof. However, there are standards that regulate the methods of microbiological tests determining the number of fungi [32] and the number of bacteria [33] in ambient air. Over the past years Canadian and Finnish recommendations regarding the maximum amount of fungi colonies in the indoor air have been announced. In accordance with these recommendations, pathogenic fungi such as: Aspergillus fumigatus, Histoplasma, Cryptococcus, and toxigenic ones such as: Stachybotrys atra, Aspergillus, Penicillium, and Fusarium should not be present in the air inside premises [4, 34].

According to the data from the literature of the subject concerning the maximum allowable quantities of micro-organism in accumulated dust, the concentration of micro-organisms shall not exceed $1.5 \cdot 10^{4} \mathrm{cfu} / \mathrm{g}$ in the case of mould and $3.0 \cdot 10^{4} \mathrm{cfu} / \mathrm{g}$ for bacteria respectively [35]. Therefore, the microbiological condition of the air in the examined facility can be considered satisfactory. However, the number and type of micro-organisms present in the air must be constantly monitored.

When compared with the plant examined here, much higher quantities of the micro-organism were detected 
by Szulc et al. [5], who analyzed the level of microbial contamination existing in the dust in the biomass power plant. They demonstrated that in the dusts coming from plants processing biomass there was from $3.29 \cdot 10^{4}$ to $3.86 \cdot 10^{5} \mathrm{cfu} / \mathrm{g}$ of moulds and from $1.68 \cdot 10^{6}$ to $3.51 \cdot 10^{7} \mathrm{cfu} / \mathrm{g}$ of bacteria depending on the type of plant material being treated. The highest degree of contamination was characterized by wood chips, while dust originating from sunflower pellets was contaminated the least. The studies have shown the presence of 10 different species of bacteria and moulds, including potential pathogens such as Candida tropicalis, Escherichia coli, Prevotella sp., Aspergillus sp., and Penicillium sp. Due to the presence of potential pathogens and mycotoxins, the levels of microbial contamination in biomass processing plants should be constantly monitored, just like in herb processing facilities.

Polednik et al. [36] demonstrated that despite the automation of the beer bottling process, periodic increases in the concentrations of the measured contamination was observed. The average mass concentrations of all measured aerosol fractions had similar values and equalled c. $0.2 \mathrm{mg} / \mathrm{m}^{3}$. The highest quantitative concentrations were measured in the case of small particles. The average concentrations of particles within the fraction size $0.3-0.5 \mu \mathrm{m}$ and $0.5-1 \mu \mathrm{m}$ were 847 and 93 particles $/ \mathrm{cm}^{3}$ respectively. In the case of biological contamination the average concentration of bacteria in the air within the beer bottling plant was $1441 \mathrm{cfu} / \mathrm{m}^{3}$, while the average concentration of fungus equalled $557 \mathrm{cfu} / \mathrm{m}^{3}$. Wojdalski et al. [37] presented a technological scheme of production processes and operations that can be used while continuing research on the influence of herb processing plants on the environment, also taking into account the explosiveness.

\section{Conclusions}

Our analysis enabled us to assess the working conditions at workstations in an herb processing plant. The average concentration of dust with particle size $\mathrm{PM}_{10}$ within both of the studied production lines exceeded the alarm level (i.e., the level of over $0.300 \mathrm{mg} / \mathrm{m}^{3}$ ). The type of raw material processed at a particular processing line is an important factor. The examination of the concentration of airborne organic dust showed that the MAC values were exceeded (more than 7 times the alarm level), and the highest short-term exposure to dust was observed for line II, where the processing of cistus was carried out.

Moulds belonging to the species Aspergillus fumigatus and Penicillium Citriunum constituted the dominant microflora in the air within the herb processing plant. A much higher level of microbial contamination was detected in the case of production line number II, which may result from morphological biodiversity of plants and other conditions of their cultivation. The presence of organic dust and mould at the workstations in the herb processing plant necessitates constant monitoring of the levels of dust concentration and microbial contamination in the establishment.

\section{Conflict of Interest}

The author declares no conflict of interest.

\section{References}

1. GÓRA A., MACKIEWICZ B., KRAWCZYK P., GOLEC M., SKÓRSKA C., SITKOWSKA J., CHOLEWA G., LARSSON L., JAROSZ M., WÓJCIK-FATLA A., DUTKIEWICZ J. Occupational exposure to organic dust, microorganisms, endotoxin and peptidogycan among plansts processing workers in Poland. Annals of Agricultural and Environmental Medicine, 16, 143, 2009.

2. MACKIEWICZ B., SKÓRSKA C., DUTKIEWICZ J. Relationship between concentrations of microbiological agents in the air of agricultural settings and occurrence of work-related symptoms in exposed persons. Annals of Agricultural and Environmental Medicine, 22 (3), 473, 2015.

3. TSAPKO V.G., CHUDNOVETS A.J., STRENBOGEN M.J., PAPACH V.V., DUTKIEWICZ J., SKÓRSKA C., KRYSIŃSKA-TRACZYK E., GOLEC M. Exposure to bioaerosols in the selected agricultural facilities of the Ukraine and Poland - a review. Annals of Agricultural and Environmental Medicine, 18, 19, 2011.

4. KARPACIŃSKI E.A. Exposure to inhalable flour dust in Canadian flour mills. Applied Occupation and Environmental Hygiene, 18 (12), 1022, 2003.

5. SZULC J., OTELEWSKA A., OKRASA M., MAJCHRZYCKA K., SULYOK M., GUTAROWSKA B. Microbiological contamination at workplaces in combined heat and power (CHP) stadion processing plant biomass. International Journal Environmental Research Public Health, 14 (1), 99, 2017.

6. FRĄC M., OSZUST M., OSZUST K., KOCIRA A., KOCIRA S. Molecular identification of fungi isolated from Dracocephalum Moldavica L. seeds. Agriculture and Agricultural Science Procedia, 7, 74, 2015.

7. PEARSON C., LITTELEWOOD E., DOUGLAS P., ROBERSTSON S., GANT T.W., HANSELL A.L. Exposures and health outcomes in relation to bioaerosol emissons from composting facilities: A systematic review of occupational and community studies. Journal of Toxicology Environmental Health, 18, 43, 2015.

8. DYKEWICZ, M.S. Occupational asthma: Current concepts in pathogenesis diagnosis, and management. Journal of Allergy and Clinical Immunology, 123 (3), 519, 2009.

9. KUSKOWSKA K., DMOCHOWSKI D. Analysis of the distribution of suspended particulate dust concentrations $\mathrm{PM}_{10}, \mathrm{PM}_{2,5}, \mathrm{PM}_{1,0}$ at different heights of the Gadński Bridge. Zeszyty Naukowe SGSP, 53 (3), 101, 2016.

10. BHATIA R., ALIKHAN A., MAIBACH H.I. Contact urticaria: present scenario. Indian Journal of Dermatology, 54, 264, 2009. 
11. MOSCATO G., PALA G. Occupational allergy to foodderived allergens. AIMS Allergy and Immunology, 1 (1), 21, 2017.

12. ŻUKIEWICZ-SOBCZAK W., CHOLEWA G., KRASOWSKA E., CHMIELEWSKA-BADORA J., ZWOLIŃSKI J., SOBCZAK P. Rye grains and the soil derived from under the organic and conventional rye crops as a potential source of biological agents causing respiratory diseases in farmers. Postępy Dermatologii Alergologii, 30 (6), 373, 2013.

13. MENGA J., LIUA J., FANB S. KANGC S., YIA K., CHENGD Y., SHENE X., TAOA S. Potential health benefits of controlling dust emissions in Beijing. Environmental Pollution, 213, 850, 2016.

14. VAN DER WALT A., LOPATA A.L., NIEUWENHUIZEN N.E., JEEBHAY M.F. Work-related allergy and asthma in spice mill workers - The impact of processing dried spices on IgE reactivity patterns. International Archives of Allergy Immunology, 152, 271, 2010.

15. ŻUKIEWICZ-SOBCZAK W., CHOLEWA G., KRASOWSKA E., ZWOLIŃSKI J., SOBCZAK P., ZAWIŚLAK K., CHMIELEWSKA-BADORA J., PIĄTEK J., WOJTYŁA A. Pathogenic fungi in the work environment of organic and conventional farmers. Postępy Dermatologii Alergologii, 29 (4), 256, 2012.

16. KOZAK M., SOBCZAK P., ŻUKIEWICZ-SOBCZAK W. Health properties of selected herbal plants. Health Problems of Civilization. 10 (2), 64, 2016.

17. VITULLO M., RIPABELLI G., FANELLI I.I., TAMBURRO M., DELFINE S., SAMMARCO M.L. Microbiological and toxicological quality of dried herbs. Letters of Apply Microbiology, 52 (6), 573, 2011.

18. GRAJEWSKI J., BŁAJET-KOSICKA A., TWARUŻEK M., KOSICKI R. Occurrence of mycotoxins in Polish animal feed in years 2006-2009. Journal of Animal Physiology and Animal Nutrition, 96 (5), 870, 2012.

19. KOSALEC I., CVEK J., TOMIĆ S. Contaminants of medicinal herbs and herbal products. Arh. Hig. Rada. Toksikol., 60 (4), 485, 2009.

20. MAESTRELLI P., BOSCHETTO P., FABBRI L.M., MAPP C. Mechanisms of occupational astma. Journal of Allergy and Clinical Immunology, 123 (3), 531, 2009.

21. CHOWDARY S.V., PRASANNA L., SANGRAM V., RANI S. KUMMAR V. Role of fungi (molds) in allergic airway disease - An Analysis in a South Indian Otolaryngology center. Indian Journal of Allergy Asthma Immunology, 25 (2), 67, 2011.

22. ŻUKIEWICZ-SOBCZAK W. The role of fungi in allergic diseases. Postępy Dermatologii Alergologii, 30 (1), 430, 2013.

23. LARONE D.H. Medically Important Fungi- a guide to identification, $5^{\text {th }}$ ed.; ASM Press: Washington, USA, 2011.

24. PN-EN ISO 4833-1:2013. Microbiology of the food chain. Horizontal method for the enumeration of microorganisms. Part 1: Colony count at 30 degrees $\mathrm{C}$ by the pour plate technique, 2013.
25. ST. GERMAIN G., SUMMERBAL R. Identifying Fungi: a Clinical Laboratory Handbook, $2^{\text {nd }}$ ed.; Star Publishing: Belmont, USA, 2011.

26. GOLDMAN E., GREEN L.H. Practical Handbook of Microbiology, $2^{\text {nd }}$ ed.; CRC Press, Taylor and Francis Group: New York, USA, 2008.

27. WHO Air quality guidelines for particulate matter, ozone, nitrogen dioxide and sulfur dioxide. Global update 2005. WHO, 2006. On-line: http://whqlibdoc.who.int/hq/2006/ WHO_SDE_PHE_OEH_06.02_eng.pdf

28. Regulation of the Minister of the environment from 24.08.2012 on the level of certain substances in the air (Dz.U. 2012, poz. 1031), 2012.

29. SOBCZAK P., ZAWIŚLAK K., ŻUKIEWICZ-SOBCZAK W., WRÓBLEWSKA P., ADAMCZUK P., MAZUR J., KOZAK M. Organic dust in feed industry. Polish Journal Environmental Studies, 24 (5), 2177, 2015.

30. BUCZAJ A. Dustiness level in selected grain processing industry plants in Lubelskie Voivodeship. Agricultural Engineering, 1 (126), 7, 2011.

31. OGÓREK R., KALINOWSKA K., PLĄSKOWSKA E., BARAN E., MAKOWSKI K. Microbiological air pollutions on different culture medium in selected room of Dermatology Department. Part II. Mikologia Lekarska, 18 (2), 79, 2011.

32. PN-89/Z-04111/03:1989 Protection of air cleanliness. Microbiological study. Determination of the number of microscopic fungi in the atmospheric air during sampling by aspiration and sedation, 1989 [In Polish].

33. PN-89/Z-04111/02:1989 Protection of air cleanliness. Microbiological study. Determination of the number of bacteria in the atmosphere when sampling by aspiration and sedation, 1989 [In Polish].

34. CHARKOWSKA A. Development of microorganisms in ventilation systems of air conditioning micro-organisms, with particular emphasis on air filters. Available online: http://1filter.pl/rozwoj-mikroorganizmow-w-instalacjachwentylacyjnych-i-klimatyzacyjnych-ze-szczegolnymuwzglednieniem-filtrow-powietrza.html (accessed on 6 May 2017), 2017 [In Polish].

35. FITZNER K., MÜLLER B., KÜCHEN V., LUSSKY J. Airless, Definition of cleanliness: Ducts. HermannRietschel-Institute for Heating and Air-Conditoning of Technical University of Berlin: Berlin, Germany, 2000.

36. POLEDNIK B., DUDZIŃSKA M., CZERWIŃSKI J., POLEDNIK A. Air quality in a brewery bottling plant. Rocznik Ochrona Środowiska, 18 (2), 591, 2016.

37. WOJDALSKI J., DRÓŻDŻ B., RAUZER A. Analiza zużycia energii $\mathrm{i}$ wody $\mathrm{w}$ zakładzie przetwórstwa zielarskiego. An analysis of energy and water consumption volumes in herb processing plant. Agricultural Engineering, 1 (99), 419, 2008 [In Polish]. 